\title{
TUBERCULOSIS: STUDIES ON ROLE OF GENDER, AGE AND DRUG ADDICTION IN EASTERN PART OF INDIA
}

\author{
Maiti $\mathbf{S}^{1^{*}}$, Patra $\mathrm{S}^{2}$, Nandi $\mathrm{D}^{3}$, Bandyopadhyay $\mathrm{B}^{4}$, Mondal K C ${ }^{5}$, Pati B $\mathbf{R}^{5}$.
}

1 Post Graduate Department of Biochemistry, Cell and Molecular Therapeutics Laboratory, Oriental Institute of Science and Technology, Midnapore, 721102, WB, India

2 Bankura Sammilani Medical College, Kenduadihi, Bankura. 722102, WB, India

3 Department of Physiology, Raja N. L. Khan Women's College, Midnapore, 721102, WB, India

4 Department of Biotechnology, Oriental Institute of Science and Technology, VIH Campus, Rangamati, Midnapore, 721102, WB, India

${ }^{5}$ Department of Microbiology, Vidyasagar University, Midnapore, 721102, WB,

\section{ABSTRACT}

Objectives: The objective of the present investigation was to determine the socioeconomic conditions, age and gender relations to tuberculosis with evaluation of drug (smoking/ alcohol) influences on it and correlate the clinical data to an animal experiment result of antioxidant system of drug treated male rats.

Settings: The investigation was carried out in a rural and an urban part of Eastern India.

Methodology: Acid-fast bacillus (AFB) staining of sputum was performed in rural Indpur (total human individuals 498, male 384) and urban area Kamarhati (total 1017, male 735) following WHO guidelines. Catalase, superoxide dismutase (SOD) activities and level of non-protein soluble thiol (NPSH), malondialdehyde (MDA) were measured in lung of rats exposed four weeks to nicotine ( $0.2 \mathrm{mg} / \mathrm{kg}$ s.c.) and/or ethanol (20\% [w/v] at $3 \mathrm{~g} / \mathrm{kg}$ orally).

Results: Mean AFB score was greater in all age groups of Kamarhati. Smoking/alcohol alone significantly and synergistically even in greater extent increased TB severity in both places, furthering it in backward classes. Drug treatment significantly increased MDA level and SOD activity with a decrease in NPSH level and catalase activity in rat.

Conclusions: Males are greater sensitive to TB and urban area is affected more. Clinical findings paralleled with animal experiments pointing the disastrous consequences of nicotine. Up-gradation of socioeconomics in rural area, avoiding of reckless unscientific changes of demographic profile of a region, and minimization of pollutions in urban areas may diminish disease outbreak.

Key words: Tuberculosis, Rural and urban, Risk factors, Antioxidant systems, Rat lung

\section{Correspondence:}

Dr. Smarajit Maiti,

Associate Professor and Head

Post Graduate Department of Biochemistry,

Cell and Molecular Therapeutics Laboratory,

Oriental Institute of Science and Technology, Midnapore,

721102, WB, India

E. mail: maitism@rediffmail.com

\section{INTRODUCTION}

People of lower income group (LIG) in developing countries are prone to different chronic infections like gastroenteritis, respiratory tract infections, malaria, tuberculosis, and HIVIAIDS in recent years. ${ }^{1,2}$ Tuberculosis (TB) causes approximately two million deaths globally per year, more than $90 \%$ of which 
occur in developing countries. ${ }^{3}$ In spite of multi drug therapy, BCG (Bacillus Calmaette-Guérin) vaccination and other chemotherapeutic advancements, TB is still the second leading cause of death. ${ }^{4}$

Several investigations identified the risk factors for TB, but fewer in India. ${ }^{5}$ Scanty reports reveal that the TB sensitivity could be associated with environmental, economic and life-style factors which have been minimized in American and European communities. ${ }^{6,7}$ In developing countries like India, the decline in risk factors is confined to the middle and high socioeconomic groups. Recently, several government and NGO operated program have been adopted fruitfully. ${ }^{8}$ Different techniques like ELISA or genomics tools are utilized for confirmed diagnosis of TB, but rapid diagnosis by sputum staining of acidfast bacilli (AFB) is still useful for a large number of patients. ${ }^{9}$ Recently, few rural and metropolitan areas were selected in the Eastern part of India for the present investigation.

\section{OBJECTIVES}

i) To make comparison between the TB sensitivity in rural and urban areas ii) to assess the disease sensitivity (by AFB staining procedure) in relation to gender, age, drug addiction and economic status of individuals iii) as it is evident that chronic ethanol and/ or nicotine administration could result impairment of rat antioxidant system ${ }^{10}$, here male rats were treated with nicotine and/or ethanol and tested their lung antioxidant profile. These results were extrapolated to explain the clinical data on addiction associated disease sensitivity.

\section{MATERIALS}

Bovine serum albumin (BSA), thiobarbituric acid (TBA), nicotine, reduced glutathione (GSH), 5-5'-dithiobis2-nitro benzoic acid were purchased from Sigma chemicals (St. Louis, MO, USA). Sodium dihydrogen phosphate $\left(\mathrm{NaH}_{2} \mathrm{PO}_{4}\right)$, disodium hydrogen phosphate $\left(\mathrm{Na}_{2} \mathrm{HPO}_{4}\right)$, ethylenediamine tetraacetic acid (EDTA), pyrogallol, basic fuchsin, ethylene Blue, ethyl alcohol, and other chemicals used in the present investigation were of analytical grade and purchased either from SRL, India or E. Merck, India.

\section{METHODS}

\section{Study design}

This is a comparative assessment of TB sensitivity between an urban and rural area with relation to patients' age, sex, drug addiction and economic status. Clinical data has been correlated to a rat experiment on the status of drug induced lung antioxidant system

\section{Settings}

The data were collected from Indpur, a rural and intermediate Panchayat of Bankura district and from Kamarhati which is an urbanized city of North 24 Parganas district, operated by the municipality and a certain part of the area covered by Kolkata Metropolitan Development Authority (KMDA). ${ }^{11}$

\section{Study period}

The data was collected and laboratory experiment was carried out in the period of 2005 to 2009.

\section{Study population and selection of subject}

The patients and participants of this investigation were routinely diagnosed in the specialized TB division / centers in the respective block hospital of Indpur and Kamarhati. They were selected at random irrespective of their ethnicity, caste, gender and ages. But those individuals were excluded who were affected with severe diabetes, cardiovascular and chronic kidney disease or some other chronic infectious diseases.

\section{Sample size, method of sampling and data collection}

In rural Indpur, a total 498 diagnosed (male 384) and in urban area Kamarhati a total 1017 diagnosed (male 735) voluntarily participated in the present investigation. An apparently large number of individuals from several years were utilized here to minimize the intra-individual variability and possible deviations caused by some intrinsic factors. The socio-economic profiles of the participants were collected by standard questionnaire method. Here, all participants were distributed in four age groups; $\leq 15$, $16-30,31-45$ and $\geq 46$ years. Data of all three elder groups were compared with the corresponding $\leq 15$ year's age group of each sex. To verify the influence of economic condition, individuals of both sexes of all 
ages were arranged in 1+, 2+, 3+ and 4+ AFB scoring groups and their yearly incomes are compared in relation to their disease severity. All data and samples were handled by registered health professionals after prior permission of the concerned Institutional Ethical Committee. The sensitivity to TB was estimated by acid-fast bacillus staining.

\section{Acid-fast Bacillus (AFB) staining of sputum sample}

Three sputum samples (twice in successive mornings and once as spot collection on the second day) were collected from each subject. Those were stained by traditional Ziehl Neelsen (Z-N) method using carbol fuchsin, acid-alcohol and ethylene blue solutions., ${ }^{9,12}$ The Indian Government laid guidelines on Revised National Tuberculosis Control Program (RNTCP) and World Health Organization (WHO) protocol were followed in evaluating the AFB scores.

\section{Animals and drug treatment schedule}

Male rats of Wister strain, weighing 120-140 g were housed in the OIST animal resource facility and provided with rodent chow and water for one-week prior use. A total 24 rats were randomly separated in 4 groups having 6 in each. Drugs were treated for 4 weeks as follows: (1) Control rats were administered normal saline orally; (2) nicotine was administered subcutaneous (s.c.) at a dose of $0.2 \mathrm{mg} / \mathrm{kg}$; (3) ethanol $(20 \%[\mathrm{w} / \mathrm{v}])$ was given orally at a dose of $3 \mathrm{~g} /$ $\mathrm{kg}$; and (4) ethanol and nicotine were administered by the route and with the dose described above. Present treatment schedule was standardized after several dose responses testing in our laboratory. ${ }^{10}$

\section{Tissue cytosol preparation and oxidative stress} studies in rat lung

The animals were sacrificed on time and their lungs were dissected, washed with ice-cold $\mathrm{NaCl}(0.9 \%$, $w / v)$ and frozen at $-20^{\circ} \mathrm{C}$ until use. Those were homogenized in $0.1 \mathrm{M}$ chilled phosphate buffer $(\mathrm{pH}$ 7.4). Fractions of fresh homogenates were utilized for few experiments. The rest of the homogenates were spun at $10,000 \times \mathrm{g}$ for one hour in a cold centrifuge. Cytosol was preserved at $-20^{\circ} \mathrm{C}$ in several aliquots.

\section{Determination of catalase activity}

The catalase activity from lung cytosol was measured spectrophotometrically. The rate of degradation of $\mathrm{H}_{2} \mathrm{O}_{2}$, the substrate of this enzyme was observed at $240 \mathrm{~nm} .13,14$

\section{Determination of superoxide dismutase (SOD) activity}

The SOD activity from lung cytosol was determined according to the method of Marklund and Marklund (1974). The activity was expressed in unit ' $U$ ', assuming, that activity of enzyme as one unit (U) which inhibits auto-oxidation of pyrogallol by $50 \%$. 14,15

\section{Estimation of non protein soluble thiol (NPSH)}

The NPSH in lung homogenate was determined by standard DTNB $(5,5$ '- dithiobis-2-nitrobenzoic acid) method as initially described by Ellman (1959) with a slight modification. ${ }^{16-19}$ In brief, lung tissues were homogenized with $50 \mathrm{mM}$ Tris buffer, $\mathrm{pH} 7.5$, containing $250 \mathrm{mM}$ sucrose and $5 \mathrm{mM}$ EDTA. The protein of $10,000 \times \mathrm{g}$ supernatant was precipitated by sulfosalisialic acid and clear cytosol was added to 0.1 $M$ sodium phosphate buffer containing $5 \mu$ M DTNB. The level of NPSH was determined against a GSH standard curve.

\section{Estimation of malondialdehyde (MDA)}

Tissue homogenates were utilized for MDA assay by the method of Buege and Aust (1978) with a slight modification. To chelate iron and reduce its interference in peroxidation reaction of unsaturated fatty acid, $1 \mathrm{mM}$ EDTA was used in the reaction mixture. To reduce the interference caused by a yellow-orange color produced by some carbohydrates, the reaction mixture was heated at $80^{\circ} \mathrm{C}$ instead of $100^{\circ} \mathrm{C}$. Finally the MDA was measured and calculated utilizing the molar extinction coefficient of MDA $\left(1.56 \times 10^{5} \mathrm{~cm}^{2}\right)$ $\mathrm{mmol}){ }^{20,21}$

\section{Protein assay}

Proteins were estimated in all tissue samples by the method of Lowry (1951) using bovine serum albumin (BSA) as the standard protein. ${ }^{22}$

\section{Statistical analysis}

The data were statistically analyzed using Student's t-test (Fisher and Yates 1974). ${ }^{23}$ 


\section{RESULTS}

In Figure 1 the occurrences of TB in male and female (78\% and $22 \%$ respectively) are very similar in Indpur and Kamarhati whereas, it differs in different age groups of two locations. Only in Indpur, a proportionate increase of both male and female patients' number was observed in 16-30 and 31-45 years groups. In Kamarhati, the male patients of $16-30,31-45$ and $\geq 46$ year's groups showed similar occurrences (29-39\%). And in female, $57.1 \%$ diagnosed belong to $16-30$ years group. a

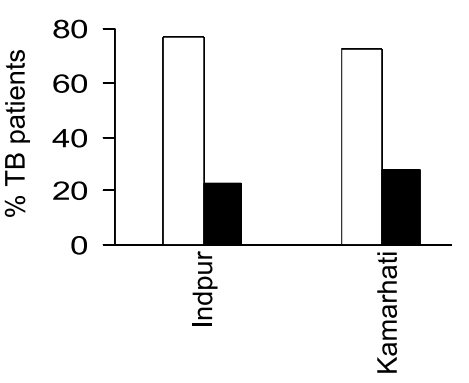

$\square$ Male

- Female b Indpur

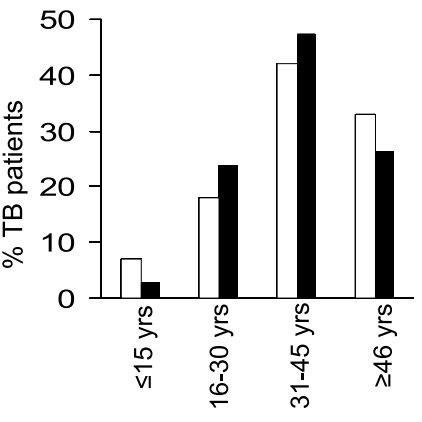

Age groups

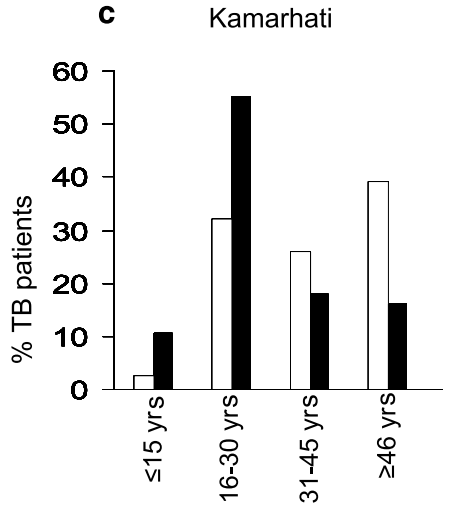

Age groups

Figure 1. The percentage of male and female TB patients attendees of rural Indpur (sample size $n=498$; male 384 ) and urban Kamarhati (sample size $n=1017$; male 735) areas (a). Percentage of same patients in different age groups of Indpur (sample size of different age groups of male; $\leq 15$ years $=27,16-30$ years $=69,31-45$ years $=162, \geq 46$ years $=126$ and female; 3, 27, 54, 30 respectively) (b) and of Kamarhati (male; 18, 237, 192, 288 and female; $30,156,51,45)$ for corresponding age groups.

The male patients of Indpur showed a significant increase of AFB score with their age increment; 1.48, 1.71 and 1.88 in 16-30, 31-45 and $\geq 46$ years groups respectively compared to the score $(0.94)$ of the $\leq 15$ years group (Figure 2 ). But in Kamarhati, AFB score of all groups of both sexes ranges from 1.39 to 1.88. The score of $\leq 15$ year's group of Kamarhati (1.43) is significantly higher (85\%) than the corresponding male group of Indpur. Similarly, all female groups show a significantly greater AFB score than the corresponding group of Indpur.

a

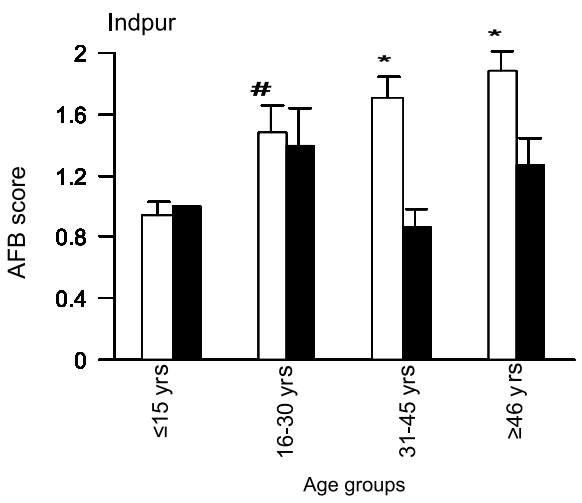

$\square$ Male

Female b

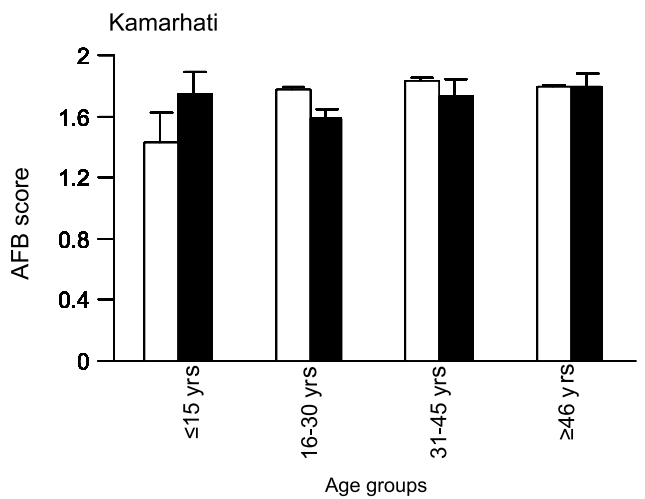


Figure 2. The AFB score of sputum smear of patients of Indpur (sample size of male; $\leq 15$ years $=27,16-30$ years $=69,31$ 45 years $=162, \geq 46$ years $=126$ and female; $3,27,54,30$ ) (a) and Kamarhati (sample size of male; 18, 237, 192, 288 and female; $30,156,51,45$ ) respectively for corresponding age groups (b). Data represented in the figure are the mean $\pm \mathrm{SEM}$. Significantly different from corresponding control. ${ }^{\#}<<0.01,{ }^{*} P<0.001$

Present results denote that mean annual income of $1+$ scoring individual of Indpur is $18,000.00$ INR/year, whereas these are $15,668.00 ; 11,170.00$ and 9654.00 INR/year of $2+, 3+$ and $4+$ scoring individuals. The same for Kamarhati are $27,150.00 ; 31,340 ; 19,560 ; 13,240$ INR/year respectively for the concerned groups (Figure 3a). The average incomes of last two AFB groups ( $3+$ and $4+$ ) of Indpur are significantly lower than the 1+ AFB group. This tendency is clearly observed in Kamarhati also. Data of Figure 3b suggest that in 'No addiction' group in Indpur, the AFB score is 1.18, where as it is 1.74 (48\% higher) in 'Smoking' group and 1.49 (27\% higher) in 'Drinking' group. In 'Smoking + Drinking' group the score is 2.335 (98\% higher). In Kamarhati, AFB score was $26 \%$ higher in 'Smoking' and $66 \%$ higher $(p<0.001)$ in 'Smoking + Drinking' groups. The score of 'No addiction' group of Kamarhati was 20\% higher than the similar group of Indpur.
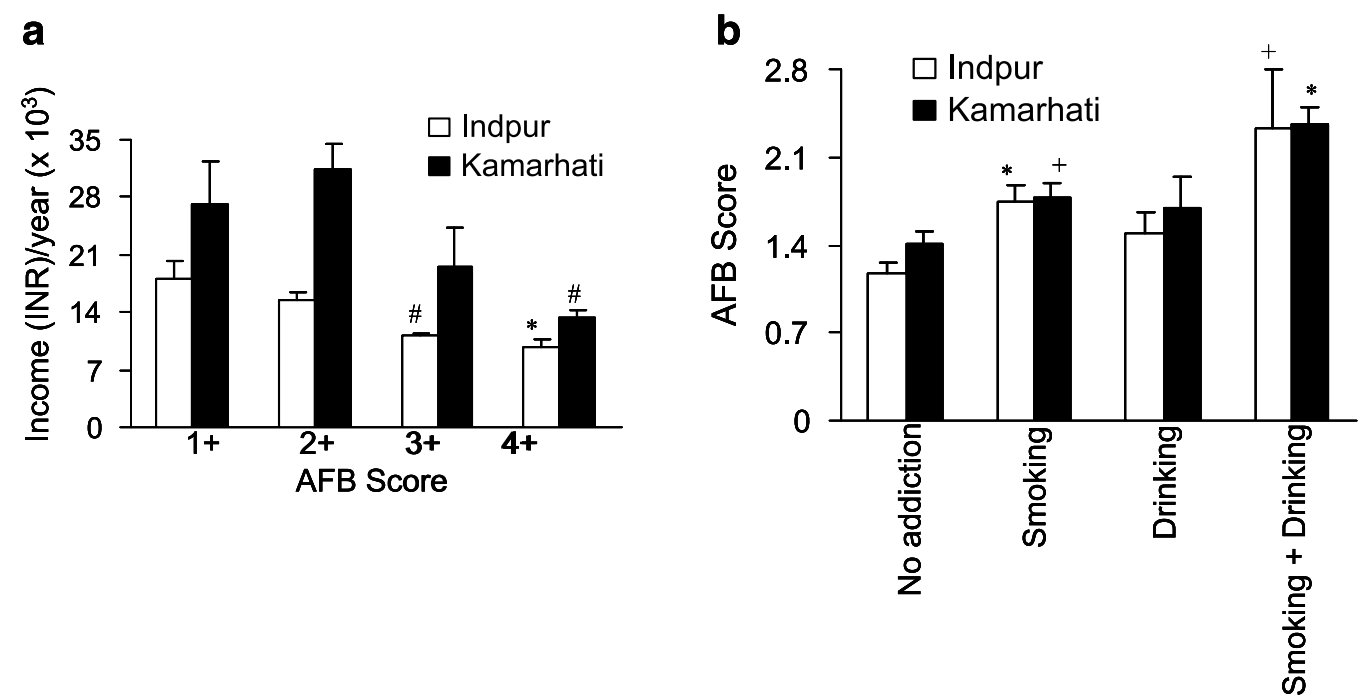

Figure 3. The impact of socioeconomic condition (income (INR)/year) on the AFB score of TB patients (210 out of 498 patients in Indpur and 698 out of 1017 of Kamarhati are in regular income. The sample size, $n$ for different AFB scoring patients in Indpur; $1+=105,2+=69,3+=24,4+=12$ and in Kamarhati these are 315, 214, 107, 67 respectively (a). The Effect of drug addiction on the AFB score of 31-45 years age groups of male of both places (sample size $n$ of Indpur; no addiction-40, smoking-34, drnking-29 and smoking + drinking-59 and similar groups in Kamarhati; 64, 39, 46, 43 respectively). The 31-45 age group is the major addicted group, and addiction in female is scare (b). Data represented in the figure are the mean $\pm \mathrm{SEM}$. Significantly different from corresponding control. ${ }^{+} \mathrm{P}<0.05$, ${ }^{*} \mathrm{P}<0.01$, ${ }^{*} \mathrm{P}<0.001$

Figure 4a1 demonstrates no variation in WBC count in normal males of different age groups of Indpur. Unlikely, the neutrophil counts in female are significantly lower $(p<0.001)$ in all age groups with comparison to $\leq 15$ years group. The lymphocyte count is also significantly lower in 16-30 years and 31-45 years age groups (Figure 4a2). A significantly higher hemoglobin value in male of 16-30 years group was observed where as, the same is lower in 16-30 and 31-45 years groups of female than their corresponding youngest groups (Figure 4b). 


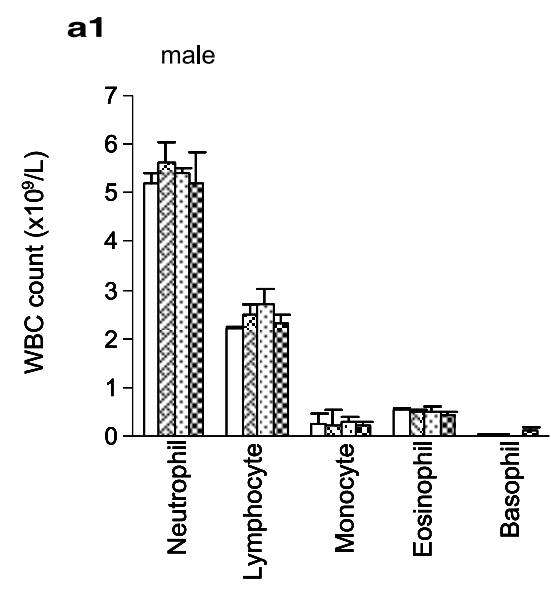

$\square \leq 15$ yrs

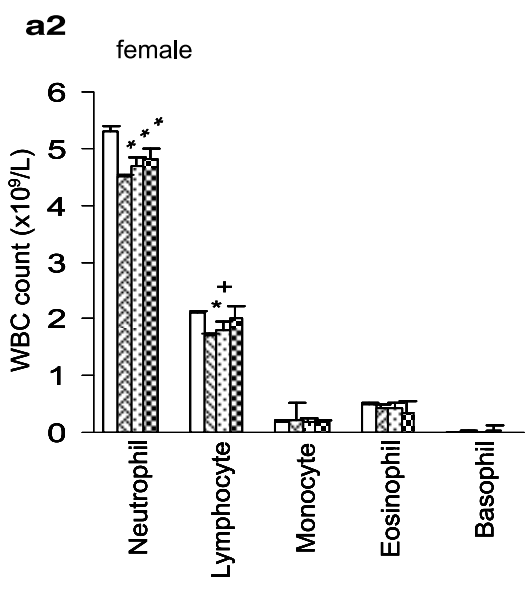

$31-45 \mathrm{yrs}$ b

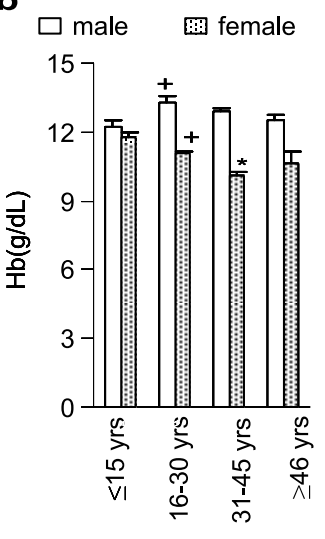

Age groups

Figure 4. Differential blood cell count of normal healthy male (a1) and female of Indpur block (a2), and their hemoglobin concentration (b) (sample sizes-n are as follows; male $\leq 15$ years $=31,16-30$ years $=78,31-45$ years $=153, \geq 46$ years $=94$ and female $68,111,165,128$ respectively. Data represented in the figure are the mean \pm SEM. Significantly different from corresponding control. ${ }^{+} \mathrm{P}<0.05,{ }^{*} \mathrm{P}<0.001$

In Figure 5a, nicotine or ethanol alone or in combination increased MDA production in rat lung $(p<0.05$ and $p<0.01$ ).Nicotine significantly decreased NPSH content in lung (Figure $5 b$ ). Nicotine or nicotine +ethanol treatment significantly increased SOD activity by $79 \%$ (Figure 5 c) whereas, catalase activity decreased in all three treatment groups (Figure 5d).
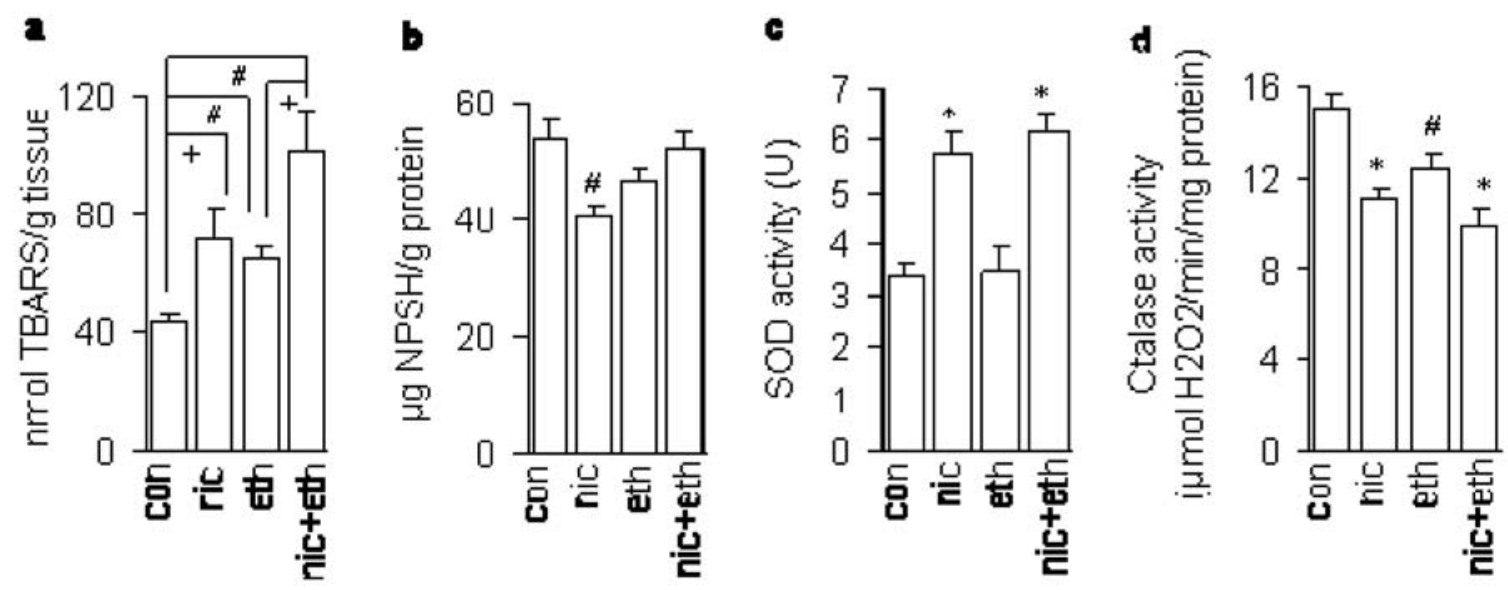

Figure 5. Effects of drug on concentrations of a) thiobarbituric acid (TBA) reactive substance- malondialdehyde (MDA) production, b) non-protein soluble thiol (NPSH), c) super oxide dismutage (SOD) and d) catalase activity in lung tissues of male Wister rats. (Sample size for any group $n=6$ ). 'Con' stands for control, similarly 'nic' for nicotine and 'eth' for ethanol. Data represented in the figure are the mean \pm SEM. Significantly different from corresponding control. ${ }^{+} P<0.05,{ }^{*} P<0.01,{ }^{*} P<0.001$. 


\section{DISCUSSIONS}

A proportionate increase in the number of male and female patients was observed in participants of different age groups in Indpur. In Kamarhati, the male patients of all the age groups showed a similar rate of occurrences (29-39\%). But in female, the highest, $57.1 \%$ diagnosed belong to $16-30$ year age group. Present results suggest that the disease sensitivity is in increasing order with increasing age in Indpur. ${ }^{24}$ Possibly, decline in immuno-potency due to nutritional lacking augments age sensitivity. ${ }^{25}$ The greater incidence of death in highest age group plausibly minimizes the number of sensitive individuals in this group. But, Kamarhati, an urban area shows similar type disease sensitivity. A certain part of Kamarhati belongs to Greater Calcutta (KMDA) which is highly populated condensed with several industries and large number of automobiles. ${ }^{11}$ The age dependant disease sensitivity as found in Indpur is absent in Kamarhati.

The highest AFB scores from all age groups of Indpur are 1.88 in male and 1.39 in female (Figure 2a). This suggests that males are more sensitive. Sex dimorphic nature of this disease sensitivity has been reported earlier. ${ }^{26}$ Results from the Figure 2 reveal that the lowest age group of both sex of Kamarhati is more affected than the corresponding groups of Indpur (1.43/1.79 Vs $0.94 / 0.96$ for male and female respectively). Present results satisfy the Figure 1 data and indicate that possible environmental pollution could be the important factors for this. ${ }^{27}$ In the 2001 census, Indpur had $51.4 \%$ males, $41.6 \%$ schedule caste and $9.5 \%$ schedule tribes. ${ }^{28}$ Decadal growths for this period were $10.15 \%$ for Indpur, against $13.79 \%$ in Bankura district and which $40.13 \%$ was in West Bengal state. ${ }^{28}$ On the other hand, Kamarhati had a $54 \%$ of male. It has an average literacy rate of $77 \%$, higher than the national average of $59.5 \%$, male literacy is $81 \%$, and female literacy is $72 \%$. The city has several industries of manufacturing of textiles, paints, articles of rubber, and products of jute. ${ }^{28}$ In spite of the advantageous demographic profile and socioeconomic standard, lower age groups of Kamarhati are more affected than Indpur. ${ }^{29}$ So, it may be hypothesized that man made unplanned changes in socio-demographic nature of an area may be more devastating than the natural adversity associated inchoate character of an area.
The economic status may be regarded as an important parameter of an individual's life style and health status. ${ }^{6,30}$ India is an over-populated country with diversified economic strength, literacy and health/ nutritional awareness. ${ }^{31}$ Results from the present investigation suggest that the individuals of lower income groups are more vulnerable to TB (Figure 3a). Toxic effects of nicotine and alcohol on immune mechanisms and antioxidant systems have been reported earlier. ${ }^{32-34}$ Our recent clinical data suggest that both drugs impart a devastating effect on TB which is additive in nature (Figure $3 b$ ). Interestingly, 'No addiction' group of Kamarhati showed $20 \%$ greater severity than the similar group of Indpur. This finding is also supported by the results of Figure 1 and Figure 2. Ironically, a better socioeconomic condition was not able to restrict disease severity in urban area (Figure 3a). Nutritional and health inequity is predominant in some of the parts of rural India. ${ }^{35-36}$ Present data from Indpur show the impairment of hemoglobin content and WBC count in young undiagnosed female.

Present outcome of rat experiment indicates that nicotine is more toxic in terms of MDA production and NPSH depletion (Figure $5 a$ and $5 b$ ) and MDA production is even greater at a co-treatment with ethanol. These results support the present clinical data showing the greater disease severity in drug addicted human individuals. Rat antioxidant enzymes have also been shown interfered after drug treatment. 34 Impairment of antioxidant profile consequences free radical mediated lung cell damage which may be associated with present clinical outcome.

In conclusion, the males are more sensitive which is furthered with drug usage especially in lower economic groups. In Indian context, drug addiction is not predominant in female but health and nutritional inequity is dominant as found in their lower immune and nutritional status. ${ }^{35-36}$ There is no doubt that the demographic profile of Kamarhatiis advantageous than Indpur. But unplanned urbanization with inadequate exhaust management may be more detrimental to disease sensitivity. In the present investigation, ethical norms on handling human subjects/ samples were maintained to our best possibilities. This is also important to mention the limitations of the present work is that, the specific differences in environmental, climatic and geographical nature of two areas and the possibilities of some individuals of having some other 
preexisting disease conditions were not taken into account at the time of comparing the TB vulnerable. Though the present rat experiment was conducted in standard laboratory condition, still its results may suggest that damage in antioxidant systems might increase TB sensitivity. We strongly hope that our present findings could be helpful for further evaluation of influences of specific factors on the course of TB progression and its nature of severity.

\section{ACKNOWLEDGEMENT}

All authors pass their humble regard to the health professionals of the concerned block hospitals and TB centers of Indpur and Kamarhati. They also offer their sincere thanks to all the participants and patients and wish a quality life to them.

\section{REFERENCES}

1. Lopez AD, Mathers CD, Ezzati M, Jamison DT, Murray CJ. Global and regional burden of disease and risk factors. 2001; systematic analysis of population health data. Lancet 2006; 367:1747-1757.

2. Muniyandi M, Ramachandran $\mathrm{R}$, Balasubramanian $R$, Narayanan PR. Socio-economic dimensions of tuberculosis control: review of studies over two decades from Tuberculosis Research Center. J Commun Dis 2006; 38:204-215.

3. Raviglione MC, Snider DE Jr, Kochi A. Global epidemiology of tuberculosis. Morbidity and mortality of a worldwide epidemic. JAMA 1995; 273:220-226.

4. Young DB, Perkins MD, Duncan K, Barry CE $3^{\text {rd }}$. Confronting the scientific obstacles to global control of tuberculosis. J Clin Invest 2008; 118:1255-1265.

5. Shah PR, Ramakrishna B, Mehta DK, Shah RC. Pulmonary tuberculosis in Ahmedabad: epidemiology, diagnosis and short course chemotherapy. Indian J Pediatr 1992; 59:435-442.

6. Leung CC, Yew WW, Tam CM et al. Socio-economic factors and tuberculosis: a district-based ecological analysis in Hong Kong. Int J Tuberc Lung Dis 2004; 8:958-964.

7. Mackenbach JP, Kunst AE, Cavelaars AE, Groenhof $F$, Geurts JJ. Socioeconomic inequalities in morbidity and mortality in western Europe. The EU Working
Group on Socioeconomic Inequalities in Health. Lancet 1997; 349:1655-1659.

8. Udwadia ZF, Pinto LM. Review series: the politics of TB: the politics, economics and impact of directly observed treatment (DOT) in India. Chron Respir Dis 2007; 4:101-106.

9. Kam KM, Yip CW, Tang HS, Van Deun A. Bulk acidfast staining of sputum smears: time to end a taboo. Int J Tuberc Lung Dis 2009; 13:1119-1123.

10. Husain K, Scott BR, Reddy SK, Somani SM. Chronic ethanol and nicotine interaction on rat tissue antioxidant defense system. Alcohol 2001; 25:89-97.

11. "Base Map of Kolkata Metroploitan area". Kolkata Metropolitan Development Authority. http:// www. cmdaonline.com/kma.html. Retrieved 2007-09-03.

12. Gupta S, Prasad V, Bairy I, Muralidharan S. Comparative evaluation of two cold staining methods with the Ziehl-Neelsen method for the diagnosis of tuberculosis. Southeast Asian J Trop Med Public Health 2009; 40:765-769.

13. Aebi H. Catalase in vitro. Methods Enzymol 1984; 105:121-126.

14. Maiti S, Chatterjee AK. Effects on levels of glutathione and some related enzymes in tissues after an acute arsenic exposure in rats and their relationship to dietary protein deficiency. Arch Toxicol 2001; 75:531537.

15. Marklund S. Spectrophotometric study of spontaneous disproportionation of superoxide anion radical and sensitive direct assay for superoxide dismutase. J Biol Chem 1976; 251: 7504-7507.

16. Ellman GL. Tissue sulfhydryl groups. Arch Biochem Biophys 1959; 82:70-77.

17. Eyer $P$, Worek F, Kiderlen $D$ et. al. Molar absorption coefficients for the reduced Ellman reagent: reassessment. Anal Biochem 2003; 312:224-227.

18. Maiti S, Grant S, Baker SM, Karanth S, Pope CN, Chen $G$. Stress regulation of sulfotransferases in male rat liver. Biochem Biophys Res Commun 2004; 323:235-241.

19. Maiti S, Dutta SM, Baker SM et. al. In vivo and in vitro oxidative regulation of rat aryl sulfotransferase IV (AST IV). J Biochem Mol Toxicol 2005; 19:109-118. 
20. Davila JC, Davis PJ, Acosta D. Changes in glutathione and cellular energy as potential mechanisms of papaverine-induced hepatotoxicity in vitro. Toxicol Appl Pharmacol 1991; 108:28-36.

21. Maiti S, Chatterjee AK. Differential response of cellular antioxidant mechanism of liver and kidney to arsenic exposure and its relation to dietary protein deficiency. Environ Toxicol Pharmacol 2000; 8:227-235.

22. Lowry $\mathrm{OH}$, Rosebrough NJ, Farr AL, Randall RJ. Protein measurement with the Folin phenol reagent. J Biol Chem 1951; 193:265-275.

23. Fisher RA, Yates R. 1974. Statistical tables for biological, agricultural and medical research. Longman Group.

24. High KP. Why should the infectious diseases community focus on aging and care of the older adult? Clin Infect Dis 2003; 37:196-200.

25. High KP. Infection in an ageing world. Lancet Infect Dis 2002; 2:655.

26. Penaloza C, Estevez B, Orlanski S et. al Sex of the cell dictates its response: differential gene expression and sensitivity to cell death inducing stress in male and female cells. FASEB J 2009; 23:1869-1879.

27. Roy S, Ray MR, Basu C, Lahiri P, Lahiri T. Abundance of siderophages in sputum: indicator of an adverse lung reaction to air pollution. Acta Cytol 2001; 45:958964.

28. "Census of India 2001: Data from the 2001 Census, including cities, villages and towns (Provisional)". Census Commission of India. Archived from the original on 2004-06-16. http:// web.archive.org / web / 20040616075334 /http:// www.censusindia.net / results $/$ town.php? stad $=\mathrm{A} \&$ state $5=999$. Retrieved 2008-11-01.

29. Lahiri T, Roy S, Basu C, Ganguly S, Ray MR, Lahiri P. Air pollution in Calcutta elicits adverse pulmonary reaction in children. Indian J Med Res 2000; 112:2126.

30. Park BH, Jung M, Lee TJ. Associations of income and wealth with health status in the Korean elderly. J Prev Med Public Health 2009; 42:275-282.

31. Purohit BC. Inter-state disparities in health care and financial burden on the poor in India. J Health Soc Policy 2004; 8:37-60.

32. John U, Rumpf HJ, Hanke M, Gerke P, Hapke U. Estimation of tobacco- or alcohol-attributable disease rates in national hospital care: an approach based on routine in-patient disease register data and systematic diagnosis of alcohol use disorders. Alcohol 2003; 38: 339-346.

33. Domagala-Kulawik J. Effects of cigarette smoke on the lung and systemic immunity. J Physiol Pharmacol 2008; 59:19-34.

34. El-Sokkary GH, Cuzzocrea S, Reiter RJ. Effect of chronic nicotine administration on the rat lung and liver: beneficial role of melatonin. Toxicology 2007; 239:60-67.

35. Kumar R, Jaiswal V, Tripathi S, Kumar A, Idris MZ. Inequity in health care delivery in India: the problem of rural medical practitioners. Health Care Anal 2007; 15:223-233.

36. Corsi DJ, Diego BG, Kumar R, Awasthi S, Jotkar R, Kaur N, Jha P. Gender inequity and age-appropriate immunization coverage in India from 1992 to 2006. BMC Int Health Hum Rights 2009; 9 (Suppl 1):S3. 